\title{
Evaluation of Limestone Interval in the Drilled Surface Section of Bn-1 Oil Well
}

\author{
Ali K. Darwesh, Thorkild Maack Rasmussen, Nadhir Al-Ansari \\ Department of Civil, Environmental and Natural Resources Engineering, Lulea University of Technology, \\ Lulea, Sweden \\ Email: nadhir.alansari@Itu.se
}

Received 2 August 2016; accepted 22 August 2016; published 25 August 2016

Copyright (C) 2016 by authors and Scientific Research Publishing Inc.

This work is licensed under the Creative Commons Attribution International License (CC BY). http://creativecommons.org/licenses/by/4.0/

(c) (i) Open Access

\section{Abstract}

The first exploration oil well in any oil block consumes in general more time and cost than the other wells in the same block. Evaluating the drilled wells serves to improve the future operations. This paper evaluates the drilled surface section through real field data for the first exploration oil well drilled in one of the oil blocks, in Kurdistan north of Iraq. The surface section of the well was drilled with the conventional method to penetrate many different geological formations with tight intervals. Drilling efficiency and the difficulties encountered are discussed and explained using various data sources. All daily drilling reports concerning a specific interval were studied. This includes weight on bit, string rotation, mud pump flow and penetration rate. Evaluation was carried out by analyzing the used controllable drilling parameters with the formations features. Penetration of the Pila Spi formation (Middle Eocene) was the most difficult formation in the drilled section. Microsoft Office 365 Pro Plus used in making graphs and Excel tables. Evaluations showed that the conventional technology used left many negative effects, like increase in None Productive Time NPT, cost and ground water pollution. Simultaneous Casing Drilling method proposed as an alternative method for the future campaign.

\section{Keywords}

Oil Exploration, Drilling, Casing, Torque, Penetration Rate, Formation, Spud

\section{Introduction}

The factors which affect the rate of penetrations are exceedingly numerous and certainly are not completely understood [1]. For that we see nowadays both evaluations and optimization of drilling process are in dynamic change based on new findings. Different methods from different disciplines are being used in drilling activities 
in order to obtain a safe, environmental friendly and cost effective well construction [2]. Evaluating those methods in any oil block is the key of success for future operations. This will start with collecting data, before, during and after the drilling campaign for each individual drilled well till we reach the decision to start the production. Based on the continuous flow of drilling data, our drilling program also has to be updated inside the main frame of the campaign program. This continuous updating will have to decrease with the increase of the numbers of drilled wells, leading to a linear increase in drilling rate and more optimized drilling parameters. Rate of penetration (ROP), weight on bit (WOB) and drill string rotation speed in round per minute (RPM) are the most controllable parameters in this evaluation [3]. (ROP) as one of the major key parameters that we can controls the time to reach the pay zone. Hence optimization of rate of penetration will greatly reduce drilling operations costs as the time to reach target depth will be reduced [4].

Finding the relation between the mentioned three parameters will serve future operations. Rate of penetration represents the amount of formation that has been drilled in time unit, and has a strong relation with both WOB and RPM. WOB is the weight of that part of the Bottom Hole Assembly (BHA) that is located exactly below the neutral the point in the drill string.

The main components of BHA are drill collars (DC) and stabilizers. Drill collars are used to provide weight for use at the bit and at the same time keep the drill pipe in tension [3]. In order to prevent the well trajectory of the drilling path and drilling string from buckling, the neutral point has to be somewhere within the BHA components during the drilling operation all the time. Based on the location of neutral point, we have to deal with both WOB and RPM in an acceptable range considering all the technical and operational limitation. Some of these limitations are related to the drill string components manufactures and some others to the drilling rig itself and the environment of operation. Here we can mention some of the main factors like the used drill bit, formation drilled, drilling fluid properties, and depth of the well, bit teeth wear and bit hydraulics [5].

The main goal of this study is to evaluate the relation between most effective parameters in drilling the Bn-1 exploration oil well in the Bazian Block. This exploration oil well was drilled in the Bazian area of Kurdistan, north of Iraq. The well pad is located at $1082 \mathrm{~m}$ above sea level on the edge of the Bazian mountain ridge. A 4.9 $\mathrm{km}$ long graded road connects the well site location to the Aghjalar-Takiya main road.

The block covers a wide area in between main three big cities Sulaimani, Kirkuk and Hawler Figure 1. This oil block is one of the 30 oil blocks that have been awarded to international oil companies in November 2008, it was the first exploration oil well in this block and the drilling was spudded on October 1st 2009. The block contains one big sub district (Aghjalar) and about 20 villages. The total population inside the boundary of the block reaches to more than 12,000 persons. The people in this block are $90 \%$ depending on winter rain and ground water for their agriculture watering and consumption.

Investigation and geophysical survey in the block begin on Dec, 2008 and finished seven months later. Drilling was started on the top of Bazian anticline structure, located at latitude $35^{\circ} 42^{\prime} 39.35^{\prime \prime} \mathrm{N}$ and longitude $44^{\circ} 54^{\prime} 33.08^{\prime \prime} \mathrm{E}$.

Two joints of conductor pipes of 30 inches' diameter have been lowered for the first $12 \mathrm{~m}$ before spud date.

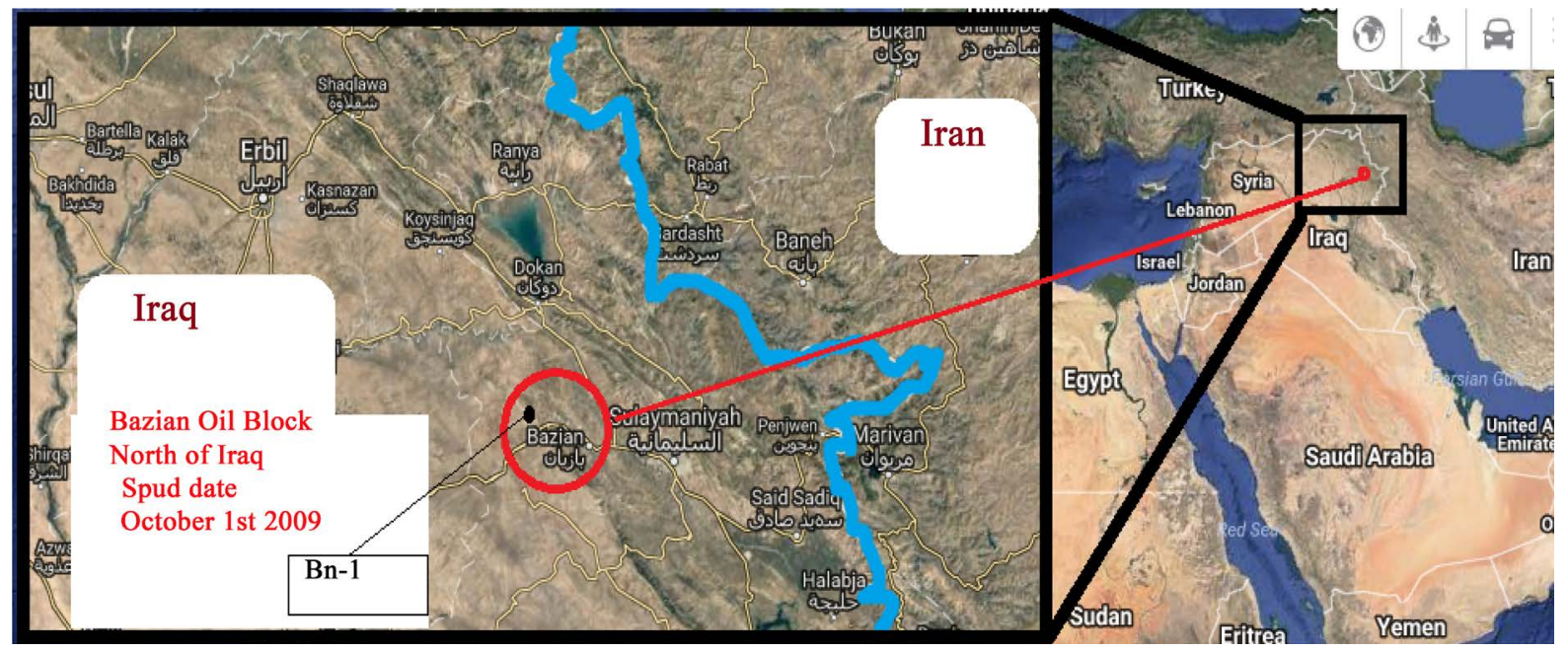

Figure 1. Location of Bn-1 [6]. 
The first BHA consisted of a 26 inches' roller cone bit, and total length of $108.53 \mathrm{~m}$ of Drill collar, Stabilizers and some accessories as given in Table 1.

The below mentioned BHA was used to drill the first section (surface section) to depth of $480 \mathrm{~m}$ using water based mud with different additives to improve mud reology. Figure 2 shows a part of the circulating system and additives on site. The surface section of the well was cased with 20 inch, grade K-55 casing to a depth of $467 \mathrm{~m}$. Based on the offset data of nearby oil fields, like 23 oil wells in TaqTaqon the west of the block and 5 oil wells in Meran oil fields to the east of the block, the lithological components of the surface section was about clear. But the exact depth to top of each formation was not known. Because of that there was a preparation for the surface section to reach $700 \mathrm{~m}$ approximately, penetrating different types of geological formation.

\section{Methodology}

The evaluation of penetrating Pila Spi formation (M. Eocene) in this paper was performed as in below points

\begin{tabular}{ccccc}
\hline Table 1. BHA\#1 components [7]-[9]. & & \\
\hline Item & Qty & OD (") & ID (") & Length (m) \\
\hline 26" & 1 & 26 & & 0.55 \\
NBS/F & 1 & 9.5 & 3 & 2.3 \\
Shock Sub & 1 & 9.5 & 3 & 4.07 \\
26" Str Stab & 1 & 26 & 3 & 2.25 \\
NMDC & 1 & 9.5 & 3.25 & 9.45 \\
26" Str Stab & 1 & 26 & 3 & 3.13 \\
NMDC & 1 & 9.5 & 3 & 9.45 \\
9" DC & 1 & 9 & 2.83 & 8.68 \\
9" DC & 1 & 9 & 2.83 & 8.78 \\
9" DC & 1 & 9 & 2.83 & 8.88 \\
9" DC & 1 & 9 & 2.83 & 8.85 \\
XO & 1 & 9.5 & $27 / 8$ & 1.09 \\
8" DC & 1 & 8 & 2.88 & 8.87 \\
8" Drilling Jar & 1 & 8 & & 5.78 \\
8" DC & 1 & 8 & 2.88 & 8.81 \\
8" DC & 1 & 8 & 2.88 & 8.83 \\
8" DC & 1 & 8 & 2.88 & 8.81 \\
Total BHA Length & & & & $\mathbf{1 0 8 . 5 3 ~}$ \\
\hline
\end{tabular}

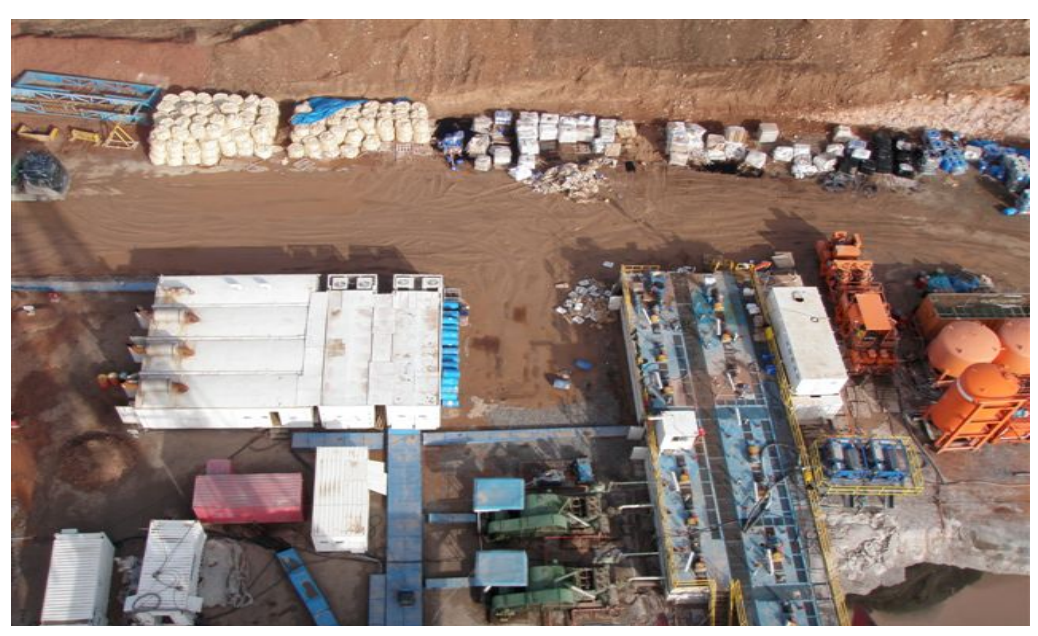

Figure 2. Circulating system and some drilling mud additives on site. 
and methodology flowchart in Figure 3:

1) Collecting daily drilling reports for the used drilling parameters like (WOB, RPM and ROP) and geological information related to real thickness of the formation or top to each formation.

2) Correlating Pila Spi formation thickness info data of three previous oil wells drilled in TaqTaq oil field and Pila Spi outcrops on the surface (near the top of Haibat Sultan Mountain to North West of Bazian block) with what have been drilled in Bn-1, Bazian Block.

3) Studying the lithology of Pila Spi formation and its relation with drilling parameters based on the most modern geological study, especially thickness, hardness variations, porosity and compatibility with depth.

4) Study of the main drilling parameters like weight on bit, rotary speed and drilling torque during the penetration Pila Spi formation in Bn-1.

5) Using MS-office and SOM software programs in finding relations between the main drilling controllable parameters and drawing.

6) Study and evaluating ROP based on Productive and none-productive time analysis.

7) Proposing more productive drilling method.

8) Studying the reason of water pollution around Bn-1.

\section{Campaign Discussion}

\subsection{Drilling Operation}

Pila Spi was the first formation of the surface section started after drilling $10 \mathrm{~m}$ of recent deposit. The actual depth to the top of Pila Spi formation was not determined exactly. Drilling continued to penetrate all the surface

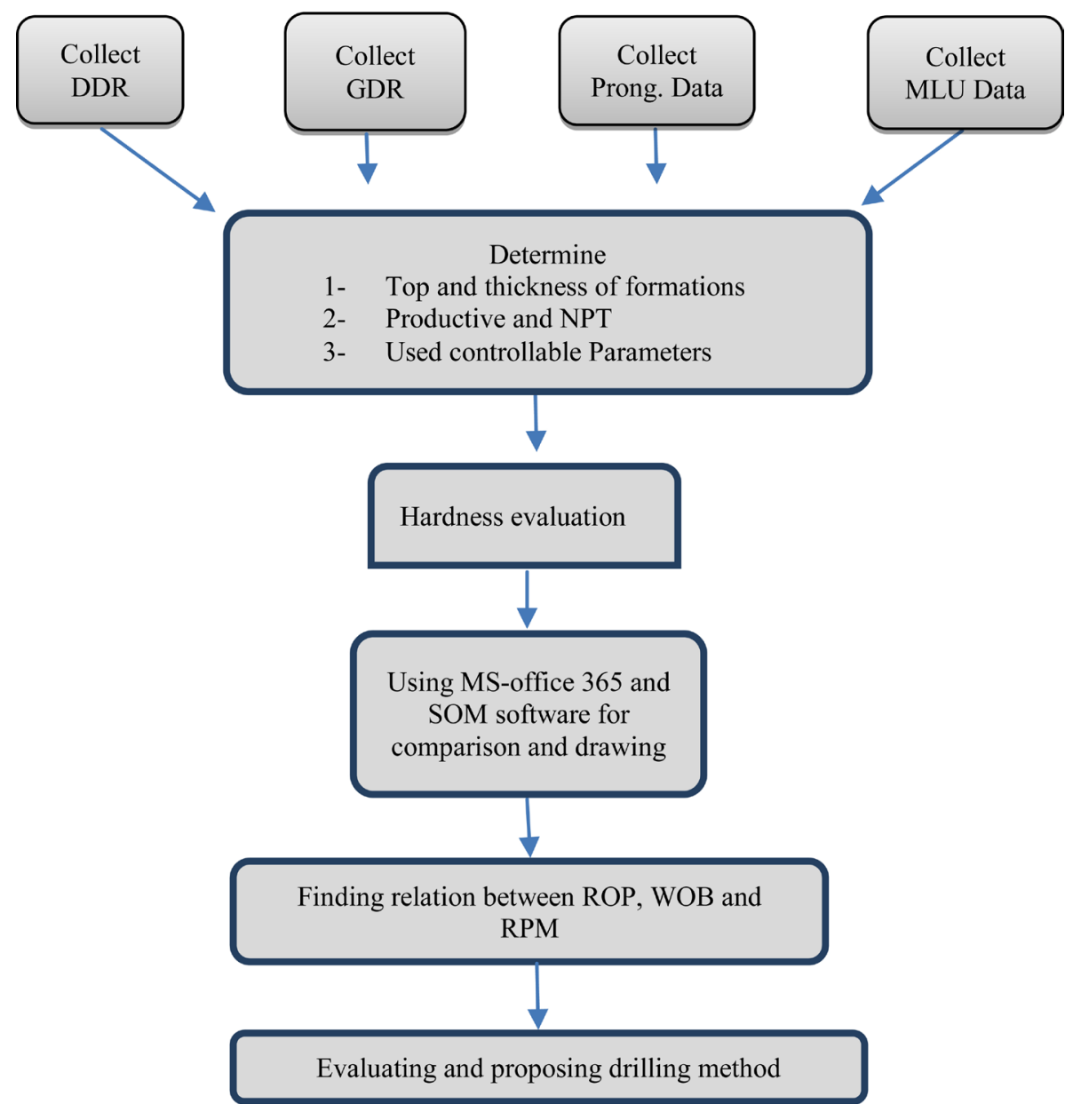

Figure 3. Methodology flowchart. 
section formations. Actual thicknesses with top of the formations of surface section based on real drilling data and Mud Logging Unit (MLU) and drill cutting are determined and listed in Table 2.

From Table 2 we can observe that there are five different formations with different physical and geological properties from the surface to $440 \mathrm{~m}$ depth, for that we can say we have tight thickness geological formations. The real thickness of Pila Spi formation based on drilling reports in this location was $137.5 \mathrm{~m}$, Measured Depth from Rotary Table (MDRT) and the rest $303 \mathrm{~m}$ comprises the other four formations thicknesses. From the beginning till finishing the drilling of the surface section, there was a lot of drilling problem. The main drilling problems were Loss of Circulation (LOC), packing and bridging, difficult because of big differences in physical and chemical properties of these formations. Table 3 contains the most important information related to the used drilling mud used with 26-inch bit in the first day of the drilling operation.

\subsection{Geological Information}

Pila Spi formation (M. Eocene), in its type section consists of two parts: The upper part of Pila Spi formation is composed of well-bedded, bituminous, chalky, and crystalline dolostone, with bands of white chalky marl with cherty nodules, especially towards the top. In the supplementary type section, dolomitic and chalky dolostone, with few dolomitized bands, chert intercalations, with traces of sub-ooliths and rare concentrations of gastropod debris, form the bulk of the formation [10]. The lower part shows well beddedhard, whitish, porous with vitreous, bituminous, or white, poorly fossiliferous dolomatic limestone with algal or shell section [11]. The lower part of the Pila Spi Formation is characterized by fractured red and brecciated dolomitic limestone, with dissolution cavities. The formation is underlain by the reddish claystones of the Gercus Formation (Lower. Eocene), and overlain by the brecciated unit of the unconformity zone, which separates the Pila Spi Formation from the clastic - carbonate strata of the Fatha (Lower Fars) Formation (M. Eocene). The sub-surface lithological characteristics and thickness of the Pila Spi formation in the area of Bazian block can be predicted through the correlation with TaqTaq oil wells and Pila Spi formation out crop on the Haibat Sultan Mountain. Figure 4 shows correlations of TaqTaq oil wells TT (2, 3, 4 and 5) with its out crop on the surface on Haibat Sultan Mountain. Formation thicknesses of the surface section after drilling are showed in Table 2. Through correlating all these data; the real data from the drilling campaign of Bn-1 we can predict the thickness of Pila Spi in all area locate between the three angles bigger area. The angle of that area is Bazian Block through Bn-1 oil well, Haibat Sultan mountain through its out crops and TaqTaq oil field through 23 oil wells.

Pila Spi formation can be recognized as a white milky chalky limestone or dolomitic limestone and very low or no primary porosity. Generally, the thickness of Pila Spi formation ranges between $(40-150) \mathrm{m}$ depending on the amount of the layer's dip. Statigraphicaly the Pila Spi formation located between Gercus formation and Lower Fars formation as can be seen in its out crop on Haibat Sultan Mountain Figure 4 and Figure 5.

Table 2. Surface section formations of Bn-1.

\begin{tabular}{|c|c|c|c|c|c|c|}
\hline Formation & $\begin{array}{l}\text { Prognosed Depth } \\
\text { (m MDRT) }\end{array}$ & $\begin{array}{l}\text { Actual Depth } \\
\text { (m MDRT) }\end{array}$ & $\begin{array}{l}\text { Prognosed Depth } \\
\text { (m TVD) }\end{array}$ & $\begin{array}{l}\text { Actual Depth } \\
\text { (m TVD) }\end{array}$ & $\begin{array}{c}\text { TVD } \pm \text { to Prognosis } \\
\text { (m) }\end{array}$ & Basis for Pick \\
\hline Pila Spi & 9.15 & $\ldots$ & 9.15 & $\ldots$ & $\ldots$ & $\ldots$ \\
\hline Gercus & 117.05 & 137.5 & 117.05 & 137.5 & +20.45 & Wireline \\
\hline Khurmala & 224.95 & 246 & 224.95 & 246 & +21.05 & Wireline \\
\hline Sinjar & 322.05 & 330 & 322.05 & 330 & +7.95 & Wireline \\
\hline Kolosh & 429.95 & 440 & 429.95 & 440 & +10.05 & Wireline/ROP \\
\hline
\end{tabular}

Table 3. Mud information for drilling surface section ([7]-[9]).

\begin{tabular}{|c|c|c|c|}
\hline Time: $14: 00$ & $\mathrm{PV}(\mathrm{cP}): 5$ & Filter Cake (mm): 1 & PH: 10.00 \\
\hline Location: Active & YP: 27 & Sand (\%): 0.1 & $\operatorname{Pm}(\mathrm{ml}): 1.20$ \\
\hline Wt. In (ppg): 8.5 & Gels 600/300: $37 / 32$ & C. Solid (\%): 4 & $\operatorname{Pf}(\mathrm{ml}): 0.30$ \\
\hline Wt. Out (ppg): 8.5 & Gels 200/100: 27/24 & LGS (\% by vol): 4 & $\operatorname{Mf}(\mathrm{ml}): 0.70$ \\
\hline Temp. In (F): & Gels 6/3: 7/5 & Wtr. (\% by vol): 96 & Chloride (mg/l): 200 \\
\hline Temp. Out $(\mathrm{F})$ : & API FI $(\mathrm{ml} / 30 \mathrm{~m}): 6.0$ & MBT (ppb eq): 16 & Total Hard (mg/l): 60 \\
\hline
\end{tabular}




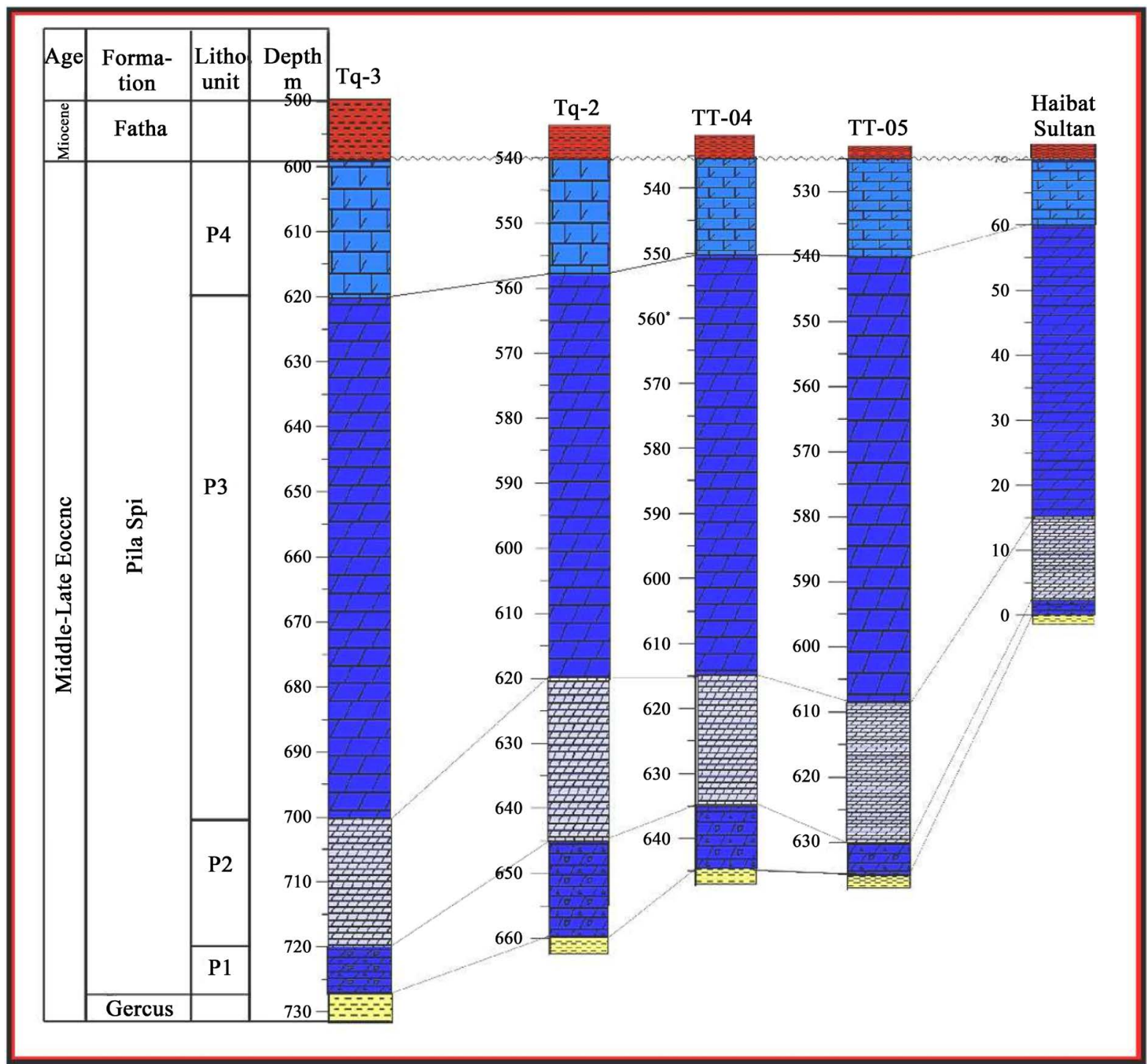

Figure 4. Lithological correlation of the Pila Spi Formation thickness across the Taq Taq oil wells and its surface out crop on Haibat Sultan Mountain ([11]).

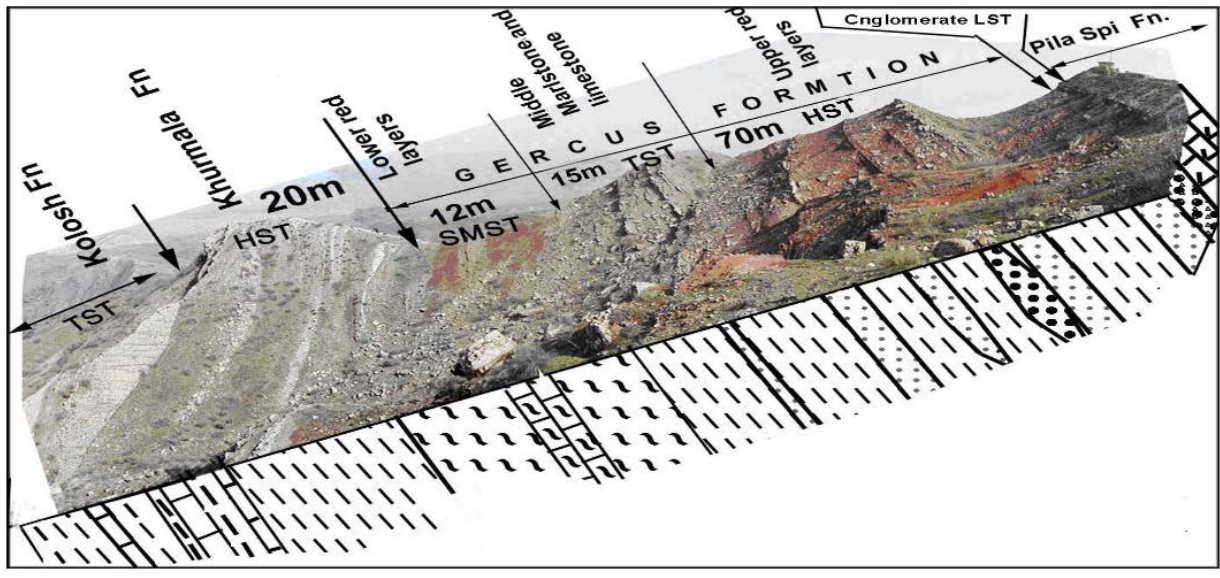

Figure 5. Scarp slop showing lithology and sequence stratigraphy of Haibat Sultan Mountain ([5]). 


\subsection{Drilling Parameters}

The time spent for drilling the surface section includes the summation of drilling, casing and cementing time up to the date of starting the drilling of the next section. The successful operation means completing those mentioned activities in planned time. Completing the operation on time can serve the environment also, beside of reducing the cost economically. Evaluating the drilling operation through the use of field data can serve to improve future operations in the same area or operations in similar geological conditions in any other place. Analyzing porosity and permeability of the formations that is penetrated is also crucial in minimizing the negative effect of uncontrollable drilling mud or cement to pollute ground water aquifers. Minimizing Non Productive Time (NPT), for the drill string and decreasing waiting time is very important. In the drilling business, all none rotating bit time is considered as none productive time. NPT will increase with any none drilling operation like reaming, pulling out of the hole, logging, or any other none drilling work. On the surface, there will be also some expected and unexpected operations that can increase NPT like any accident and maintenance after the spud date.

In case of Bn-1 drilling operation, partial mud loss began one day after the spud and increased to total loss during the third day. Figure 6 shows the lithology description from the cutting obtained in the returned mud for the times when circulation was on. The rocks were dolomitic limestone from $10 \mathrm{~m}$ to $30 \mathrm{~m}$ depth. Due to the total loss other intervals were not described through the sampling process. Blind drilling continued until the end of the surface section at depth of $480 \mathrm{~m}$ (Figure 6).

NPT as one of the important data have been recorded in Table 4. NPT in the second day of the drilling operation based on daily drilling report as an example was 7.75 hours. Based on the same analyzing principle all daily drilling reports were analyzed in Table 5. The total bit rotating hours for 19 daily drilling reports for the surface section was 147 hours which represent total productive time, while the total NPT was 309 hours. The first day NPT was 15.5 hours with productive time of 8.5 hours, and so on for the rest of the days mentioned in Table 5 .

The relationship between Weight of Bit (WOB), Rotary Speed (RPM), Torque and Rate of Penetration (ROP) with the True Vertical Depth (TVD) is illustrated in Figure 6 and Figure 7. From Figure 7 we can observe that the maximum value for torque was recorded during penetration of the last part of Pila Spi formation near the top. Generally, the drilling will be hard and need more torque in limestone fractured intervals, while the minimum string rotation was recorded when the torque was at maximum value during Pila Spi formation penetration. There is a clear resistance or torque increase for drilling operation with fluctuate rate of WOB by the driller as the normal response during the increase of torque Figure 7. The rate of penetration was not affected during the variation of torque and RPM parameters. The maximum torque value was recorded during the penetrating of Pila Spi formation. After penetrating the Pila Spi formation the drilling parameters returned back to an almost constant range. Total loss of mud circulation was from the third day of the drilling process and the NPT was increasing (Table 4) due to increase of hole problems. Most of increased NPT was from reaming and back reaming as was mentioned in the daily drilling reports. The overall NPT was 1.554 times the PT for this section. The total NPT for drilling $480 \mathrm{~m}$ and PT was 309 hours in 19 days. The drilling productivity was low and the cumulative cost was increasing rapidly. Improving efficiency can be achieved through the effective management of effort to improve productivity. The old adage "time is money" applies here with results showing up as lower drilling costs per foot and cost per well. Drillers and producers rely on five basic strategies to increase productivity and lower the costs: 1) Minimizing NPT, 2) Working Faster, 3) Working Smarter, 4) Making Better Decisions, and 5) Tailoring Rig Design for the specific Purpose [12].

The above discussion can be pointed as below:

1) Due to the fact that Pila Spi formation is composed of highly fractured rocks, most of the ground water in the area around Bn-1 location is polluted with drilling mud with harmful additives. From Figure 6 we can clearly see that the drilling resistance (Torque) increased within Pila Spi formation from $0-100 \mathrm{~m}$ and the total loss of drilling mud beyond that depth.

2) During the drilling operation time of 147 hours, at least there were $63,000 \mathrm{bbl}$ of circulated mud $(\mathrm{Q}=300$ GPM) lost in Pila Spi formation and caused the ground water pollution in the area. Change of the color of the water from water springs around Bn-1 oil well after the mud loss was directly evident.

3) All changes mentioned in the above points concerning water wells and springs took place on the west side of the Bn-1, as the structure dip was in that direction. The situation returned back to what it was before after finishing the cementing operation for the drilled section. 
4) The drilling efficiency for surface section was very low based on NPT analyses, which was 1.554 times more than PT, and raised the cost to be more than expected.

5) Stable drilling parameters, with no string vibration record indicated that the neutral point of the drill string was all the time inside BHA (BHA weight was 19.5 tons) components.

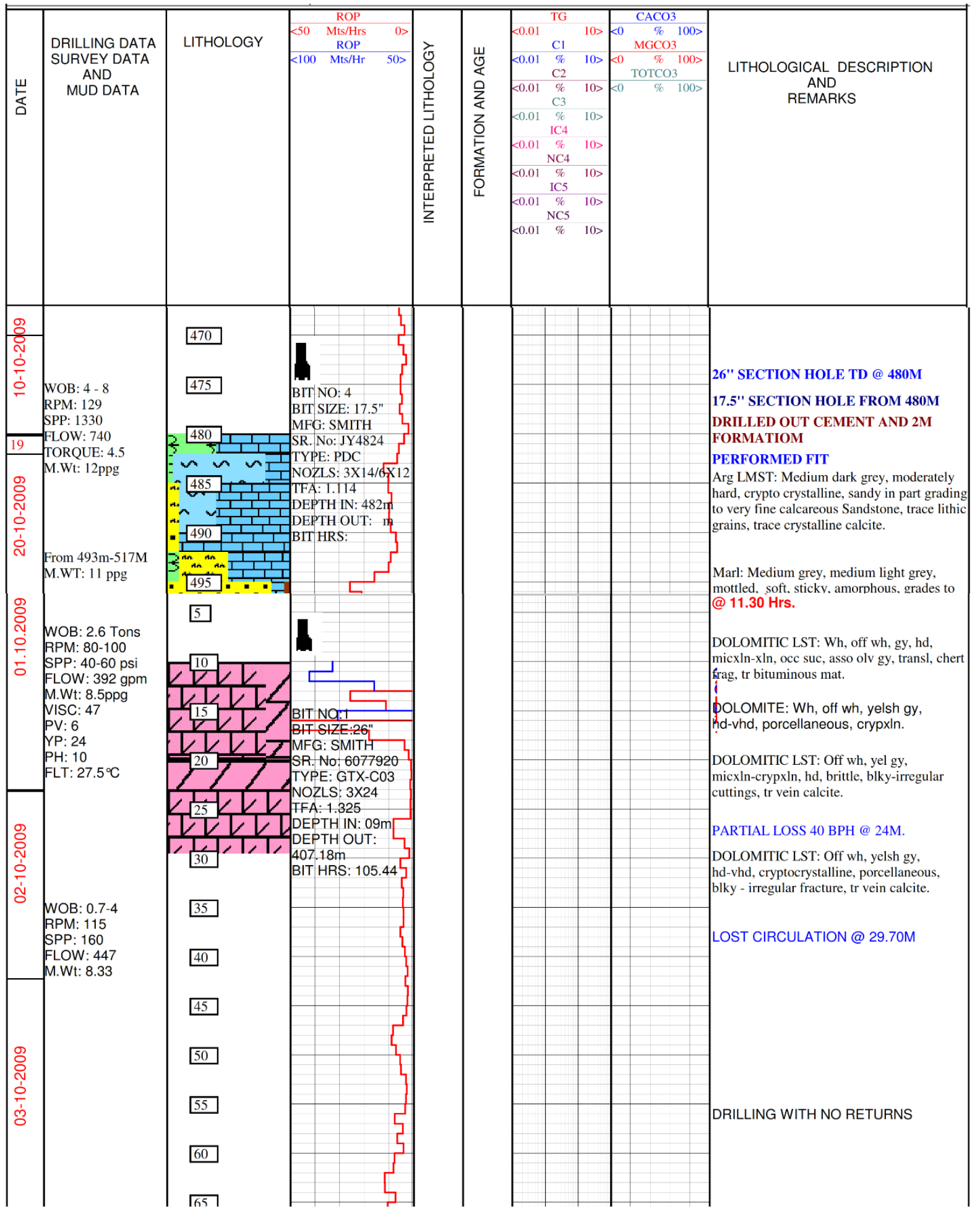

Figure 6. Mud log data for the surface section ([7]-[9]). 
6) Decrease of RPM to $70 \mathrm{rpm}$, with unstable high torque $(90 \mathrm{kNm})$ during penetrating of the Pila Spi formation, with no increase in WOB indicates that the interval was highly fractured and brittle.

7) Constant WOB with high increase in torque indicate that the parameters were not well optimized to give maximum efficiency in drilling production.

8) Based on point 6 above there is a probability of shifted neutral point to somewhere above the BHA and this could lead to buckling or increase of inclination of the well.

\section{Conclusions}

The drilling operation indicates that Pila Spi formation is not a homogenous formation for all its thickness of $137.5 \mathrm{~m}$ in Bn-1. The upper part of the formation is more bedded and has less secondary porosity compared with the lower part which has more fractures and cavities. For that we observe the increase of mud loss with the depth that leads also to ground water pollution. Ground water pollution probability is high and will follow the dip of

Table 4. Second day drilling activities.

\begin{tabular}{|c|c|c|c|c|}
\hline No. & 24 hours & Activities & $\begin{array}{l}\text { NPT } \\
\text { Hours }\end{array}$ & $\begin{array}{c}\text { Cumulative } \\
\text { NPT }\end{array}$ \\
\hline 1 & $0-3: 30$ & POOH and make BHA \#2 also 26" & 3.5 & 3.5 \\
\hline 2 & $3: 30-4: 30$ & Ream the well from $21 \mathrm{~m}$ to $21 \mathrm{~m}$ & 1.0 & 4.5 \\
\hline 3 & $4: 30-13: 30$ & Drill to $26 \mathrm{~m}$ & 0 & 4.5 \\
\hline 4 & $13: 30-14: 15$ & $\% 100$ loss, spot 50 bbl LCM, circulation back & 0.75 & 5.25 \\
\hline 5 & $14: 15-16: 00$ & Drill to $28 \mathrm{~m}$ & 0 & 5.25 \\
\hline 6 & $16: 00-18: 00$ & Again $\% 100$ loss, spot $100 \mathrm{bbl}$, loss continued & 1 & 6.25 \\
\hline 7 & $18: 00-19: 30$ & Make up string stabilizer and $1 \times 9$ "DC, filling section tank with fresh water & 1.5 & 7.75 \\
\hline 8 & 19:30 - 00:00 & $\begin{array}{l}\text { Drill to } 42 \mathrm{~m} \text { with total loss, swept hole with } 50 \mathrm{bbls} \text { LCM. (Drilling w/300gpm - total } \\
\text { losses of } 750 \mathrm{bbls} \text { mud. Had returns up to } 85 \% \text { off and on during drilling }\end{array}$ & 0 & 7.75 \\
\hline
\end{tabular}

Table 5. Time analyzing for Pila Spi Pentration.

\begin{tabular}{|c|c|c|c|c|c|c|}
\hline No. & Day & PT (h) & Cumulative PT (h) & NPT (h) & Cumulative NPT (h) & Depth (m) \\
\hline 1 & 01-Oct-09 & 8.5 & 8.5 & 15.5 & 15.5 & 23.1 \\
\hline 2 & 02-Oct-09 & 16.25 & 24.75 & 7.75 & 23.25 & 42 \\
\hline 3 & 03-Oct-09 & 18.75 & 43.5 & 5.25 & 28.5 & 105 \\
\hline 4 & 04-Oct-09 & 6.5 & 50 & 17.5 & 46 & 126 \\
\hline 5 & 05-Oct-09 & 21.5 & 71.5 & 2.5 & 48.5 & 206 \\
\hline 6 & 06-Oct-09 & 21 & 92.5 & 3 & 51.5 & 281 \\
\hline 7 & 07-Oct-09 & 20.75 & 113.25 & 3.25 & 54.75 & 356 \\
\hline 8 & 08-Oct-09 & 14.75 & 128 & 9.25 & 64 & 407 \\
\hline 9 & 09-Oct-09 & 14.5 & 142.5 & 9.5 & 73.5 & 469 \\
\hline 10 & 10-Oct-09 & 3.5 & 146 & 20.5 & 94 & 480 \\
\hline 11 & 11-Oct-09 & 0 & 146 & 24 & 118 & 480 \\
\hline 12 & 12-Oct-09 & 0 & 146 & 24 & 142 & 480 \\
\hline 13 & 13-Oct-09 & 0 & 146 & 24 & 166 & 480 \\
\hline 14 & 14-Oct-09 & 0 & 146 & 24 & 190 & 480 \\
\hline 15 & 15-Oct-09 & 0 & 146 & 24 & 214 & 480 \\
\hline 16 & 16-Oct-09 & 0 & 146 & 24 & 238 & 480 \\
\hline 17 & 17-Oct-09 & 0 & 146 & 24 & 262 & 480 \\
\hline 18 & 18-Oct-09 & 0 & 146 & 24 & 286 & 480 \\
\hline 19 & 19-Oct-09 & 1 & 147 & 23 & 309 & 480 \\
\hline
\end{tabular}


(a)

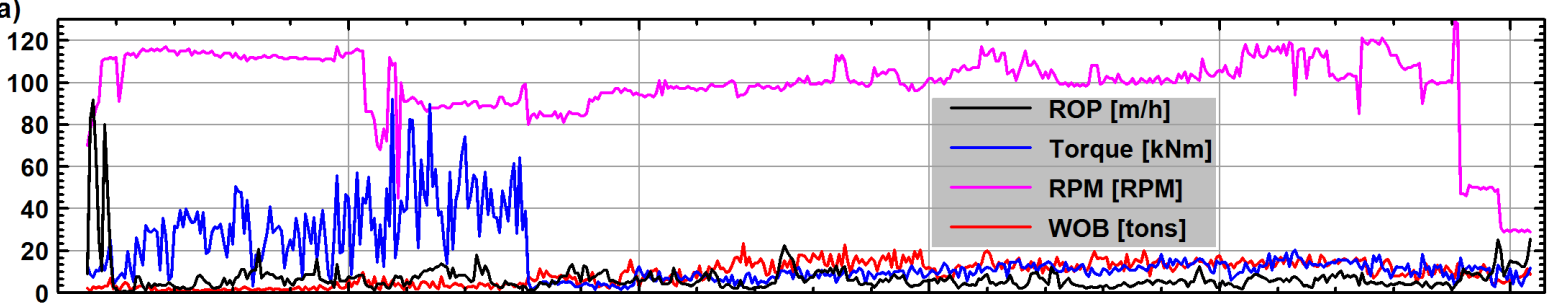

(b)

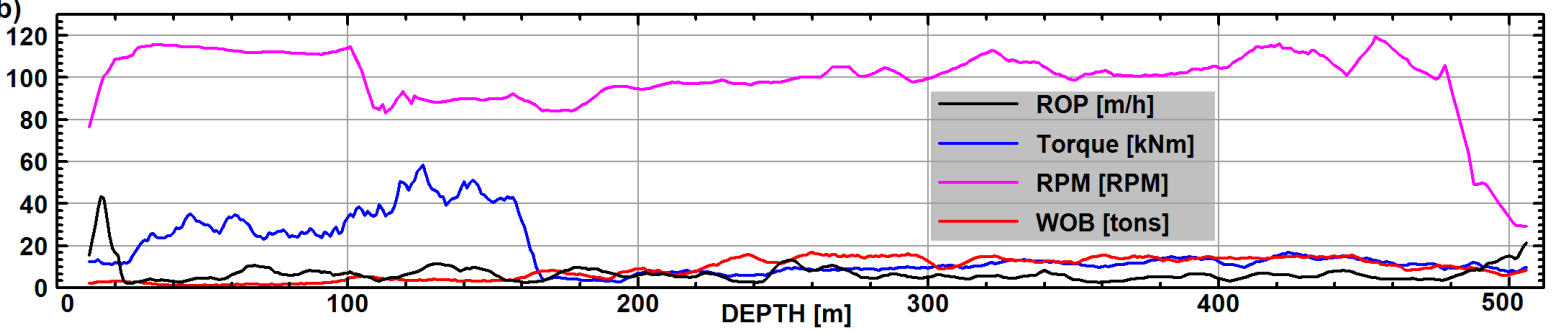

Figure 7. Drilling parameter changes with depth, (a) without smoothing and (b) with smoothing to one order.

beds in the area.

Drilling problems probability is higher in the lower part of Pila Spi formation compared to the upper part because of brittle features in the lower part. Optimizing drilling parameters like WOB, RPM and Mud pump flow rate $\mathrm{Q}$ can be set for both parts of the formation (Upper and Lower) as two different sets of parameters.

To reduce NPT in the overall operation, casing while drilling can be considered as an alternative option to conventional drilling. With this technique there will be no need to wiper trips, reaming and bit changing also. This will help to save more than 200 hours (NPT) from 309 hours spending on wiper trips, reaming and bit changing, so with the new drilling technology we can enhance the efficiency and decrease the cost up to $40 \%$. Using CWD with fresh water can be considered for future operation and it can serve the area environmentally and decrease pollution.

\section{References}

[1] Gatlin, C. (1960) Drilling and Well Completions. Department of Petroleum Engineering, University of Texas, Texas.

[2] Eren, T. (2010) Real-Time-Optimization of Drilling Parameters during Drilling Operations.

[3] Rabia, H. (2002) Well Engineering \& Construction. Entrac Consulting Limited, London.

[4] Alum, M.A. and Egbon, F. (2011) Semi-Analytical Models on the Effect of Drilling Fluid Properties on Rate of Penetration (ROP). Nigeria Annual International Conference and Exhibition, 30 July-3 August 2011, Abuja. http://dx.doi.org/10.2118/150806-MS

[5] Bourgoyne Jr., A.T., Chenevert, M.E., Milheim, K.K. and Young Jr., F.S. (1986) Applied Drilling Engineering. Society of Petroleum Engineers, Richardson, TX.

[6] ShaMaran (2012) Total to Acquire ShaMaran Taza Oil Field in Kurdistan. http://www.2b1stconsulting.com/total-in-the-race-to-kurdistan-with-exxonmobil-and-chevron/

[7] Korea National Oil Corporation, KNOC (2009) MLU Data (No. MLOG 0-627). KNOC, Kurdistan.

[8] Korea National Oil Corporation, KNOC (2009) Daily Drilling Reports (Drilling Report No. 3). KNOC, Kurdistan.

[9] Korean National Oil Corporation, KNOC (2009) Daily Geological Report (Geological on Site Report No. 21). KNOC, Kurdistan.

[10] Jassim, S.Z. and Goff, J. (2006) Geology of Iraq. Printed in the Czech Republic: Dolin, Hlavin 2732, Prague and Moravian Museum Zelny trh 6, Brno, Czech Republic, 2006.

[11] Othman, D.H. and Al-Qayim, B.A. (2010) Lithofacies Association, Dolomitization, and Potentiality of the Pila Spi Formation, Taq Taq Oil Field, Kurdistan Region, Ne Iraq. Iraqi Bulletin of Geology and Mining, 6, 95-114.

[12] Cochener, J. (2010) Quantifying Drilling Efficiency. Office of Integrated Analysis and Forecasting US Energy. 


\section{Submit or recommend next manuscript to SCIRP and we will provide best service for you:}

Accepting pre-submission inquiries through Email, Facebook, LinkedIn, Twitter, etc.

A wide selection of journals (inclusive of 9 subjects, more than 200 journals)

Providing 24-hour high-quality service

User-friendly online submission system

Fair and swift peer-review system

Efficient typesetting and proofreading procedure

Display of the result of downloads and visits, as well as the number of cited articles

Maximum dissemination of your research work

Submit your manuscript at: http://papersubmission.scirp.org/ 